\title{
Fatty acid signature analysis confirms foraging resources of a globally endangered Mediterranean seabird species: calibration test and application to the wild
}

\author{
Reijo Käkelä1,2,* Anne Käkelä ${ }^{1}$, Alejandro Martínez-Abraín ${ }^{3}$, Blanca Sarzo ${ }^{4}$, \\ Maite Louzao $^{3,6}$, Cati Gerique ${ }^{4}$, Elena Villuendas ${ }^{4}$, Ursula Strandberg ${ }^{1}$, \\ Robert W. Furness ${ }^{5}$, Daniel Oro ${ }^{3, * *}$ \\ ${ }^{1}$ Faculty of Biosciences, University of Joensuu, PO Box 111, 80101 Joensuu, Finland \\ ${ }^{2}$ Department of Biological and Environmental Sciences, University of Helsinki, PO Box 65, 00014 Helsinki, Finland \\ ${ }^{3}$ Institut Mediterrani d'Estudis Avançats IMEDEA (CSIC-UIB), Miquel Marquès 21, 07190 Esporles, Mallorca, Spain \\ ${ }^{4}$ Centro de Recuperación de Fauna Granja de El Saler, Conselleria de Medio Ambiente, Avda. de los Pinares 106, El Saler, \\ 46012 Valencia, Spain \\ ${ }^{5}$ Faculty of Biomedical and Life Sciences, Graham Kerr Building, University of Glasgow, Glasgow G12 8QQ, UK
}

${ }^{6}$ Present address: Centre d'Etudes Biologiques de Chizé, CNRS, 79360 Villiers en Bois, France

\begin{abstract}
Dietary studies of seabirds provide information on food webs and oceanographic variability. Studying fatty acid signatures (FAS), which reflect changes in the composition of the diet, has several advantages over traditional methods. In the context of the Mediterranean marine ecosystem, we studied tissue FAS in captive-fed and wild seabirds. Yellow-legged gulls Larus michahellis were experimentally fed either pelagic (sardine Sardina pilchardus) or demersal (spotted flounder Citharus linguatula) fish for $8 \mathrm{wk}$, and FAS in the birds' plasma and adipose tissue were studied. The FAS developed patterns characteristic of the sardine or flounder diet, showing the reliability of both types of samples. In addition, plasma samples of 20 endangered wild Balearic shearwaters Puffinus mauretanicus and their most likely prey items from the Mediterranean Sea were collected and analyzed for FAS. Based on FAS of Mediterranean fish, and the results from the feeding experiment, the diet of the endangered wild shearwaters was estimated. In terms of the composition of polyunsaturated fatty acids, the plasma FAS of the shearwaters resembled those of the captive gulls kept on a sardine diet, suggesting that pelagic feeding resources dominate shearwater diet. However, the high level of 20:1n-11, likely metabolized from 22:1n-11 by the birds themselves, suggested that the diet also contained a demersal component rich in $22: 1 \mathrm{n}-11$. Contrary to the situation in the open oceans, the levels of the C20 and C22 monounsaturated fatty acids are low in the Mediterranean food web and characteristic of most demersal species. Our results support the findings of previous field studies that the diet of the shearwaters is frequently supplemented by demersal fish from fishery discards.
\end{abstract}

KEY WORDS: Adipose tissue $\cdot$ Fatty acid signatures $\cdot$ Feeding ecology $\cdot$ Seabird-fishery interactions Larus · Puffinus · Shearwater · Plasma · Yellow-legged gull

\section{INTRODUCTION}

Obtaining accurate information on temporal and spatial changes in food web structure and functioning is crucial for a successful ecosystem-based manage- ment approach. Changes in the environmental conditions, either of natural or of human origin, might cause bottom-up effects that could be amplified through the food web and manifested by top predators (Sergio et al. 2005). Since seabirds are marine top predators, they 
are good indicators of ecosystem status and environmental change (Arcos et al. 2008). Many seabirds that feed on fish or plankton are likely to have their food resources reduced or relocated due to anticipated effects of climate change on lower trophic levels (Wells et al. 2008). At least as important as the effects of global climate change are fishery-seabird interactions that have aroused concern worldwide. Population sizes of many seabirds have been found to reflect changes of fish stocks or amounts of discards provided by fisheries (Garthe \& Hüppop 1994, Garthe et al. 1996, Oro \& Ruiz 1997, Oro 1999, Louzao et al. 2006a, Furness et al. 2007).

The Mediterranean is an oligotrophic marine ecosystem with some locally productive hot spots influenced by marine currents and the input of freshwater run-off, such as in the Ebro Delta area (Arnau et al. 2004). This small marine ecosystem sustains modest (but locally large) fisheries and rather small (but largely endemic) seabird populations (Salat 1996, Zotier et al. 1999). Fisheries provide an important part of the energetic demands of many of these endemic seabirds (Oro 1999, Arcos \& Oro 2002). Fishing by bottom trawlers and purse seine fleets is very well developed, especially in the western basin. Fisheries remove a significant proportion of biomass and, due to high discarding rates, return food in a highly predictable way that is exploited by opportunistic scavenging seabirds (Arcos et al. 2008). Discards, totaling ca. $565000 \mathrm{t} \mathrm{yr}^{-1}$ in the whole Mediterranean and Black Sea (Alverson 1998), are mainly composed of under-sized fish or fish of low commercial value (both demersal and pelagic species) plus small amounts of offal. The benefits to seabirds of consuming discards, especially enhanced breeding performance, have been well demonstrated during periodic closures of trawl fishing in the Ebro Delta since 1991 (Oro et al. 1995, 1996). Also in other marine ecosystems, increases in the numbers of scavenging seabirds have been linked to the extra food made available over several decades by fishery discards (e.g. Thompson \& Riddy 1995, Garthe et al. 1996, Votier et al. 2004, 2008, Svane 2005). However, if fishery waste is reduced, large scavenging seabirds may switch to killing smaller bird species (Votier et al. 2004).

In order to monitor and forecast changes in food webs, there is an increasing need to develop and validate novel tools, including tissue biomarkers, to complement the traditional methods of diet study, which have several biases (Barrett et al. 2007). Fatty acid signatures (FAS) have been found to be among the most promising and sensitive biomarkers for revealing temporal and/or spatial differences in the diets of seabirds and other free-ranging marine predators (Barrett et al. 2007, Iverson et al. 2007, Käkelä et al. 2007, Thiemann et al. 2007, Wang et al. 2009). The main requirement for studying the feeding ecology of top predators by means of fatty acids is that their prey species, or types of prey, differ in their FAS. When clear differences are found, the FAS have proven to be ideal for identifying inter- and intra-species differences in seabird diet (Dahl et al. 2003, Käkelä et al. $2005,2006,2007$ ). Even quantitative estimations of the composition of diet have been made based on adipose tissue biopsies (Iverson et al. 2004, 2007, Wang et al. 2007).

In this study, we investigated the feeding ecology of the critically endangered Balearic shearwater Puffinus mauretanicus in the western Mediterranean, comparing the FAS of the birds' plasma to the FAS of their most likely prey species. The Balearic shearwater is among the most threatened seabirds in the Palearctic region and is endemic to the Balearic Islands (Oro et al. 2004). During the breeding season, its main foraging ground is located off the eastern Iberian Peninsula where the species specializes in foraging on small pelagic fish, although a bioenergetic model estimated that over $40 \%$ of the energetic demands of the total population was met by trawling discards (including both demersal and pelagic fish) during the breeding season (Arcos \& Oro 2002). In order to calibrate the FAS between shearwaters and their prey, we firstly conducted a feeding trial with captive yellow-legged gulls Larus michahellis fed with either pelagic fish (sardine Sardina pilchardus) or demersal fish typical of trawling discards (Atlantic spotted flounder Citharus linguatula). The FAS were studied in plasma samples of captive gulls, which could indicate a switch in diet in a few days, and in adipose tissue, which has a slower turnover of fatty acids (FAS integrated over weeks; Käkelä et al. 2005, 2009). We aimed to (1) determine if pelagic and demersal prey species of the Mediterranean contain distinguishable fatty acid markers, (2) perform a calibration test to examine the transfer of pelagic and demersal fatty acid markers to plasma and adipose tissue of birds, (3) estimate the contribution of pelagic and demersal prey in the diets of wild birds using plasma, and (4) compare the estimated diets of wild birds to data from a previous study (Arcos \& Oro 2002).

\section{MATERIALS AND METHODS}

Feeding experiment with captive yellow-legged gulls. Ten yellow-legged gulls that had been admitted to a rehabilitation center in eastern Spain were kept in captivity (January to March 2005) and were fed with mixed pelagic and demersal fish for 8 wk before the experiment. After this period, the captive birds had a similar dietary background and consequently similar fatty acid profiles of adipose tissue and plasma before the feeding experiment (Supplementary Material, 
Fig. S1, available at: www.int-res.com/articles/suppl/ m398p245_app.pdf). The gulls were then divided into 2 homogenous groups of 3 adults and 2 subadults (firstwinter individuals). The feeding experiment was conducted under permit from the regional environmental agency (Generalitat Valenciana/Conselleria de Medio Ambiente) following ethical guidelines, and under veterinarian control. At the start of the experiment, the diet of 1 group ( $n=5$ ) was switched to the demersal species, Atlantic spotted flounder, and the diet of the other group $(n=5)$ to the pelagic sardine. These experimental diets (1.5 $\mathrm{kg} \mathrm{d}^{-1}$ group $^{-1}$ ) were provided for another 8 wk. Each week, 10 randomly selected sardines and flounders were measured and weighed. The average biometric values for the whole $8 \mathrm{wk}$ were as follows (mean $\pm \mathrm{SD}$ ): sardine length $18 \pm 3 \mathrm{~cm}$ and weight $45 \pm 19 \mathrm{~g}$; flounder length $16 \pm 1 \mathrm{~cm}$ and weight $36 \pm 14 \mathrm{~g}$. For both species, 6 randomly selected specimens were frozen at $-20^{\circ} \mathrm{C}$, stored at $-80^{\circ} \mathrm{C}$, and later homogenized whole in the analytical laboratory for lipid and fatty acid analysis.

The birds were weighed, and adipose tissue and plasma samples were taken at the start and end of the feeding experiment. In both groups, the birds weighed 800 to $1200 \mathrm{~g}$ and had average left wing lengths of 39 to $41 \mathrm{~cm}$. Body weights of the birds showed no significant changes during the experiment $(\mathrm{p}=0.81$, 1 -way analysis of variance, ANOVA). Blood was sampled from the metatarsal vein and centrifuged to separate plasma. To obtain adipose tissue, a small subcutaneous cut was made close to the knee, and approximately $50 \mathrm{mg}$ of adipose tissue were removed by an experienced veterinarian, $24 \mathrm{~h}$ after the previous meal. The samples were flushed with nitrogen, frozen in airtight Eppendorf Safe-Lock ${ }^{\circledR}$ polypropylene vials, transported frozen to the analytical laboratory, and stored for $1 \mathrm{mo}$ at $-80^{\circ} \mathrm{C}$ until the analysis.

Sampling of Balearic shearwaters and their potential prey species. During the chick-rearing period, breeding Balearic shearwaters were captured by hand at the entrance of the main accessible colony (Mallorca Island) on 15 June 2003, and blood was sampled (with the permission of the regional environmental authority, Govern de les Illes Balear) from the metatarsal vein of 20 birds. As it proved to be too difficult to safely obtain samples of body fat from these protected and endangered live birds, no body fat was collected. To prevent blood clotting, EDTA was added to the blood samples, which were then centrifuged to separate plasma. In addition, 6 specimens of each of 9 likely prey species of Balearic shearwaters were collected during the spring of the same year in 2 different foraging grounds: the Ebro Delta area and the Balearic archipelago (Arcos \& Oro 2002, Louzao et al. 2006b). During the breeding season, shearwaters are present in shallow shelf and coastal waters on the Iberian continental shelf, but other areas within the foraging range of the species could be important foraging areas such as the Balearic archipelago or Algerian coast (North Africa; Ruíz \& Martí 2004, Louzao et al. 2006b). Thus, we collected 3 pelagic species (sardine, bogue Boops boops, and Mediterranean horse mackerel Trachurus mediterraneus; the former is a planktivore and the 2 latter are predatory species) from local fishing boats of Mallorca, and also 2 pelagic species (sardine and anchovy Engraulis encrasicholus; planktivores) from an experimental oceanographic cruise across the Ebro Delta area (Mediterranean International Trawl Survey, MEDITS; Bertrand et al. 2002). Demersal species were also collected from the same cruise: European hake Merluccius merluccius, greater forkbeard Phycis blennoides, silvery pout Gadiculus argenteus, crocodile lanternfish Lampanyctus crocodilus, and common bobtail Sepieta oweniana (Cephalopoda). The demersal reference data were supplemented with a sample of Atlantic spotted flounders used as diet in the feeding experiment. Plasma and fish samples were stored at $-80^{\circ} \mathrm{C}$ for 2 to 3 mo before analysis.

Fatty acid and lipid analysis. The total lipid content and lipid class composition of the dietary fish and the plasma samples were analyzed using thin-layer chromatography-flame ionization detection (TLC-FID analyzer, Iatroscan new Mark V, Iatron Laboratories). The total lipids were first extracted in glass vials with chloroform:methanol (2:1, vol:vol) according to Folch et al. (1957) and then separated on chromarods. Petroleum ether:diethyl ether:formic acid (67:2.2:0.75 by vol) was used as the eluent. Two replicates were analyzed, and the detector responses were calibrated with authentic quantitative lipid standards (Sigma).

Fatty acid composition was determined in yellowlegged gull and shearwater plasma, gull adipose tissue, and homogenates of whole fish. Representative subsamples were transmethylated in glass vials by heating for $120 \mathrm{~min}$ at $95^{\circ} \mathrm{C}$ with $1 \% \mathrm{H}_{2} \mathrm{SO}_{4}$ in methanol (containing hexane as cosolvent) under a nitrogen atmosphere, and the formed fatty acid methyl esters (FAMEs) were extracted with hexane in 2 steps. The dried and concentrated FAMEs were analyzed by a gas-liquid chromatograph (GC) using both FID and mass detection (MSD; 6890N network GC with FID and 5973 MSD, Agilent) and DB-wax capillary columns (30 m, ID $0.25 \mathrm{~mm}$, film $0.25 \mu \mathrm{m}$, J\&W Scientific). A volume of $2 \mu \mathrm{l}$ was injected, and the split ratio was $1: 20$. The injectors were set at $250^{\circ} \mathrm{C}$, and the FID and mass interphase were at 250 and $200^{\circ} \mathrm{C}$, respectively. Helium was used as a carrier gas $\left(1.8 \mathrm{ml} \mathrm{min}^{-1}\right.$

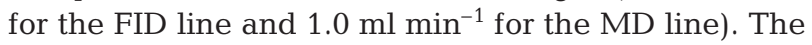
initial oven temperature of $180^{\circ} \mathrm{C}$ was held for $8 \mathrm{~min}$, programmed to rise $3^{\circ} \mathrm{C} \mathrm{min}-1$ to a final temperature of 
$210^{\circ} \mathrm{C}$, which was kept for $25 \mathrm{~min}$. Agilent Chemstation software was used for peak area integration and extraction of mass spectra. The identification of the FAMEs was based on retention time, mass spectrum, and comparisons to authentic (Sigma) and natural standards of known composition and published reference spectra (www.lipidlibrary.co.uk/ms/ masspec.html). Quantifications were based on FID responses corrected according to the theoretical response factors (Ackman 1992) and calibrations with quantitative authentic standards. The fatty acid proportions were calculated as molar \%, and the fatty acids were marked by using the abbreviations: [carbon number]:[number of double bonds] n-[position of the first double bond calculated from the methyl end] (e.g. 22:6n-3). Calibration factors to account for the lipid metabolism in a bird's body were calculated for the fatty acid percentages in plasma total lipids versus the percentages in diet, and for the levels in adipose tissue total lipids versus the dietary levels ([FA mol\% in tissue]/[FA mol\% in diet], listed completely in the Supplementary Material, Table S1, available at: www. int-res.com/articles/suppl/m398p245_app.pdf). When discussing dietary effects on variations of individual fatty acids in seabird plasma, the present data from yellow-legged gull and shearwater plasma were supported by further examination of previous data on captive herring gulls Larus argentatus fed pelagic or demersal Atlantic fish (Käkelä et al. 2005, 2009).

Multivariate analysis of fatty acid data. To analyze relationships between the plasma samples from the calibration test with gulls as well as samples from wild shearwaters and dietary fish, data were subjected to multivariate principal component analysis (PCA) using the SIRIUS 7.1 software package (Pattern Recognition Systems; Kvalheim \& Karstang 1987). In each group, sample size was block normalized and the values were arcsine transformed. The samples positioned in multidimensional space were plotted in 2 new coordinates (principal components, PC1 and PC2) calculated to describe the largest and second largest variance of the fatty acid data among the samples. To quantify the observed differences between the sample groups, space-filling models were created for 2 of the groups at a time, and distances of the samples (standardized to homogenize the variable weights) to these models were computed by soft independent modeling of class analogies (SIMCA; included in the SIRIUS software package) at $\mathrm{p}<0.05$ (Wold \& Sjöström 1977).

\section{RESULTS}

\section{Feeding experiment with yellow-legged gulls}

The fatty acid composition of the fatty pelagic sardine (4 wet weight \% [wwt\%] lipid) differed in many respects from the lean demersal Atlantic spotted flounder (1 wwt\% lipid). Compared to the sardine, the flounder contained in general more monounsaturated fatty acids (MUFAs); levels of 16:1n-7, 17:1n-8, and $18: 1 \mathrm{n}-9$ of the flounder were double the sardine levels, but the minor components $22: 1 \mathrm{n}-11$ and 24:1n-9 were lower in flounder than in sardine $(\mathrm{p}<0.05$, Student's $t$ test). The flounder was also rich in $n-6$ polyunsaturated fatty acids (PUFAs); levels of 20:4n-6, 22:4n-6, and $22: 5 n-6$ were twice those of the sardine, but $18: 2 n-6$ was slightly less abundant in flounder than in sardine ( $p<0.05)$. In contrast, the flounder contained less $n-3$ PUFAs: $18: 3 n-3(0.2 \times$ less abundant), 18:4n-3 (0.1×), $20: 5 n-3(0.5 \times)$, and $22: 6 n-3(0.7 \times)$, but $22: 5 n-3$ was more abundant $(2.2 \times)$ than in the sardine $(p<0.05$; Fig. 1).

After $8 \mathrm{wk}$ on the experimental diets, the adipose tissue FAS of the gulls differed from the starting FAS (Supplementary Material, Fig. S1) and resembled those of their new diets. The above mentioned large dietary differences in individual MUFAs were reflected in the adipose tissue FAS, and the gulls fed flounder had also deposited less 18:4n-3, 20:5n-3, and 22:6n-3 ( $p<0.05$ for all the mentioned fatty acids, Student's $t$-test; Fig. 2A). However, there were certain differences between the dietary and adipose tissue FAS (Fig. 2B). In the adipose tissue, the levels of the poten-

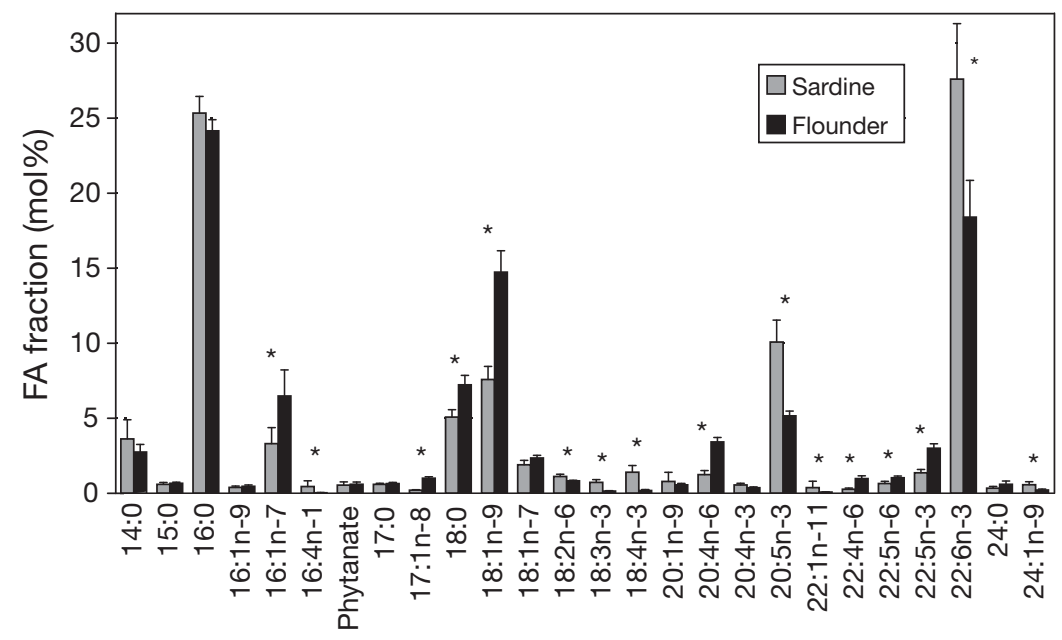

Fig. 1. Sardina pilchardus and Citharus linguatula. Main fatty acids $(\mathrm{mol} \%$, mean $\pm \mathrm{SD}, \mathrm{n}=6$ each) in sardine and Atlantic spotted flounder (total lipids of the homogenates of whole fish) fed to captive yellowlegged gulls (fatty acids exceeding $0.3 \mathrm{~mol} \%$ in either fish are shown). Asterisks denote significant differences $(\mathrm{p}<0.05$, Student's $t$-test) between the 2 species of fish 
tially endogenous fatty acids $18: 0$ and $18: 1 \mathrm{n}-9$ had twice the proportions found in the diet. In addition, 22:1n-11 and the isomers of C20 MUFA were present with several times higher percentages in the adipose tissue than in the diet. In contrast, the levels of the highly polyunsaturated fatty acids (e.g. 20:5n-3 and $22: 6 n-3)$ were only one-half or one-third of the dietary levels, respectively (the calibration factors of different fatty acids were in general individual and very different, and no statistics were applied to compare them). In the 2 feeding groups, the calibration factors for the whole array of fatty acids showed similar patterns. However, the individual calibration factors differed between the 2 dietary groups for 19 of 36 fatty acids ( $p<0.05$, Student's $t$-test; Fig. 2B, full list of calibration factors provided in Table $\mathrm{S} 1$ ).
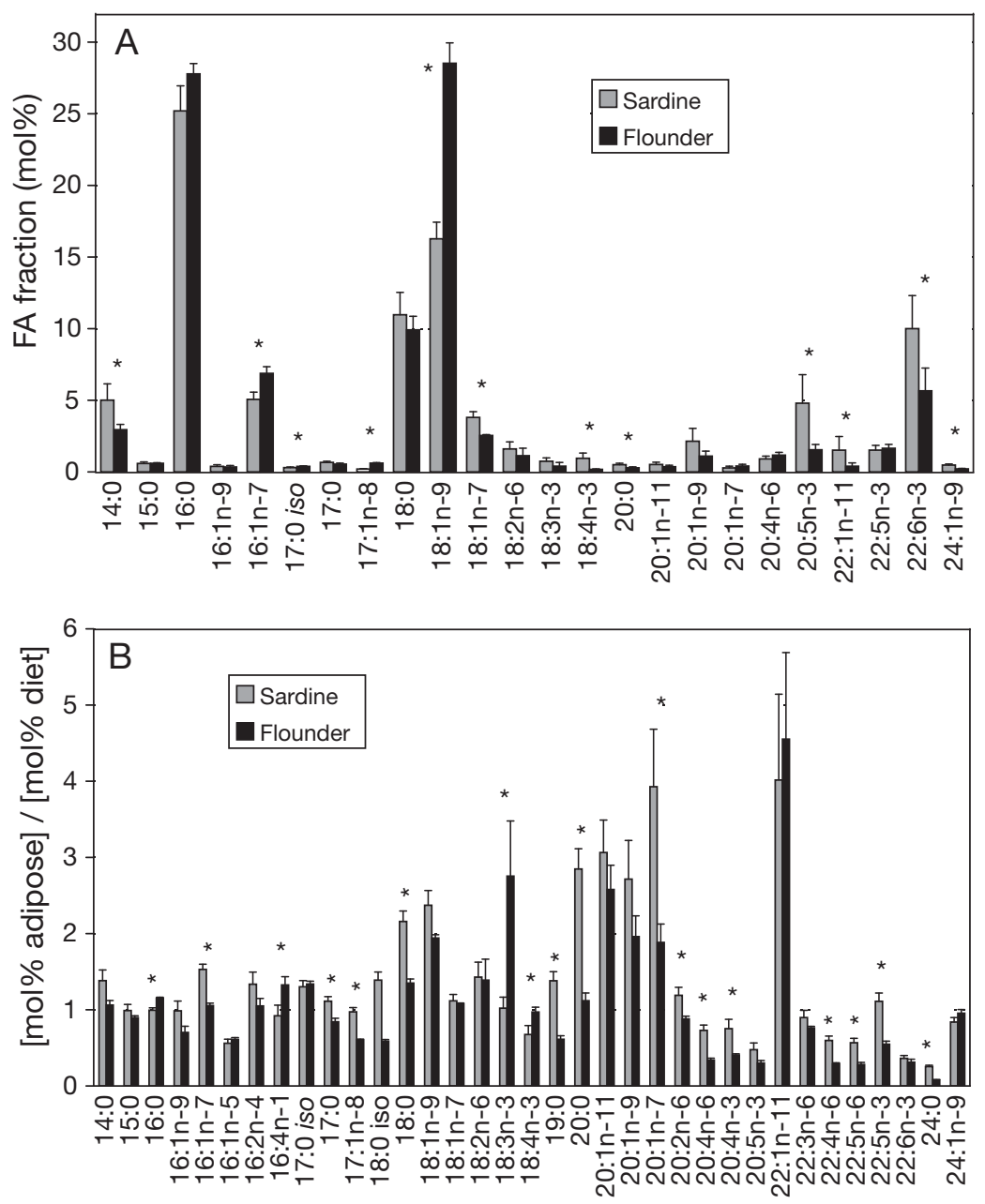

Fig. 2. Larus michahellis. (A) Main fatty acids (mol\%, mean $\pm \mathrm{SD}, \mathrm{n}=5$ each) in the total lipids of adipose tissue of captive yellow-legged gulls fed the experimental sardine and Atlantic spotted flounder diets (fatty acids exceeding $0.3 \mathrm{~mol} \%$ in either group are shown). (B) Calibration factors between the proportions in the adipose tissue and diet. Asterisks denote significant differences $(\mathrm{p}<0.05$, Student's $t$-test) between the 2 dietary groups
The FAS of plasma for both feeding groups differentiated during the feeding experiment, and the fatty acid characteristic of the sardine and flounder that were elevated in the FAS of the adipose tissue were also more abundant in plasma samples (Fig. 3A). The plasma of the gulls fed flounder contained 1.5 to 2 times more 17:1n-8, 18:1n-9, 20:4n-6, 22:4n-6, and 22:5n-6, about 3 times less 18:2n-6, 18:3n-3, and 20:5n3 , and slightly less $17: 0,18: 1 n-7,20: 3 n-6$, and 22:6n-3 than the plasma of the gulls fed sardine ( $p<0.05$ for all, Student's $t$-test). However, the shifts in the general levels of many fatty acids from diet to tissue were more pronounced in the plasma than in the adipose tissue of the yellow-legged gulls (Figs. 2 \& 3). For instance, the levels of $18: 0$ and $20: 4 n-6$ in plasma were triple and quadruple the levels in the diet, respectively, whereas 18:1n-9 was doubled in both tissues compared to the dietary levels. Although halved in adipose tissue, in plasma the levels of 20:5n-3 (metabolic counterpart of 20:4n-6) equaled the dietary levels. The decrease in 22:6n-3 in relation to dietary values was similar to that in the adipose tissue. As was the case for the adipose tissue, the coefficients calibrating between the diet and plasma differed considerably for different fatty acids and also between the 2 feeding groups (Fig. 3B). The coefficients differed between the 2 groups at $p<0.05$ in 21 of 36 fatty acids (Student's $t$-test).

\section{FAS of wild Balearic shearwaters and their potential prey species}

Among the potential prey species of Mediterranean seabirds, the pelagic sardine had the highest lipid content (8 wwt\% in the specimens caught near the Balearic Islands and 4 wwt \% at Ebro Delta) and the rest of the species were lean (1 to 3 wwt \%; Table 1). In the potential dietary items and the plasma samples of the shearwaters, 42 fatty acids were present with more than $0.2 \mathrm{~mol} \%$ in at least 1 species (Supplementary Material, Table S2, available at: www.int-res.com/articles/suppl/m398p245_ app.pdf).

Characteristic differences between the dietary items were identified by PCA (Fig. 4). The pelagic fish (sardine, anchovy, and bogue) were rich in C16 and C18 PUFAs, whereas the PUFAs of the demersal species (common bobtail, greater forkbeard, crocodile lanternfish, silvery pout, 
Table 1. Length, weight, and lipid content in the potential pelagic (PEL) and demersal (DEM) prey species of the Balearic shearwater Puffinus mauretanicus collected at the Balearic Islands (BI) and Ebro Delta (ED) in 2003, as well as the fish species collected for the feeding experiment with captive yellow-legged gulls Larus michahellis in 2005. Values for the total lipids and the main neutral storage lipid, i.e. triacylglycerol (TAG), are shown (the remaining fraction being structural polar lipids; mean \pm SD)

\begin{tabular}{|c|c|c|c|c|c|c|}
\hline Species & Scientific name & Origin & $\begin{array}{l}\text { Length } \\
\text { (cm) }\end{array}$ & $\begin{array}{l}\text { Weight } \\
\text { (g) }\end{array}$ & $\begin{array}{l}\text { Total lipids } \\
(\mathrm{wt} \%)\end{array}$ & $\begin{array}{l}\text { TAG } \\
(\mathrm{wt} \%)\end{array}$ \\
\hline \multicolumn{7}{|c|}{ Potential prey species $(n=6)$} \\
\hline Sardine & Sardina pilchardus & PEL / BI & $15 \pm 1$ & $37 \pm 3$ & $8.3 \pm 1.2$ & $4.7 \pm 1.2$ \\
\hline Sardine & Sardina pilchardus & PEL / ED & $11 \pm 2$ & $13 \pm 7$ & $4.2 \pm 3.4$ & $2.2 \pm 2.0$ \\
\hline Anchovy & Engraulis encrasicholus & PEL / ED & $10 \pm 1$ & $8 \pm 1$ & $2.5 \pm 0.8$ & $0.6 \pm 0.4$ \\
\hline $\begin{array}{l}\text { Mediterranean horse } \\
\text { mackerel }\end{array}$ & Trachurus mediterraneus & PEL / BI & $17 \pm 2$ & $41 \pm 9$ & $2.2 \pm 1.1$ & $0.5 \pm 0.5$ \\
\hline Bogue & Boops boops & PEL / BI & $16 \pm 2$ & $51 \pm 13$ & $1.5 \pm 0.3$ & $0.1 \pm 0.1$ \\
\hline Silvery pout & Gadiculus argenteus & $\mathrm{DEM} / \mathrm{ED}$ & $9 \pm 1$ & $9 \pm 2$ & $3.1 \pm 0.9$ & $1.7 \pm 0.6$ \\
\hline Crocodile lanternfish & Lampanyctus crocodilus & $\mathrm{DEM} / \mathrm{ED}$ & $12 \pm 1$ & $17 \pm 6$ & $1.5 \pm 0.5$ & $0.2 \pm 0.2$ \\
\hline European hake & Merluccius merluccius & $\mathrm{DEM} / \mathrm{ED}$ & $10 \pm 1$ & $8 \pm 3$ & $1.1 \pm 0.3$ & $0.1 \pm 0.0$ \\
\hline Greater forkbeard & Phycis blennoides & $\mathrm{DEM} / \mathrm{ED}$ & $10 \pm 2$ & $7 \pm 3$ & $1.8 \pm 0.4$ & $0.2 \pm 0.1$ \\
\hline Common bobtail & Sepieta oweniana (Cephalopoda) & $\mathrm{DEM} / \mathrm{ED}$ & $5 \pm 1$ & $5 \pm 2$ & $3.0 \pm 0.5$ & $0.1 \pm 0.0$ \\
\hline \multicolumn{7}{|l|}{ Feeding experiment $(n=6)$} \\
\hline Sardine & Sardina pilchardus & PEL / ED & $17 \pm 2$ & $34 \pm 10$ & $4.2 \pm 2.7$ & $2.1 \pm 2.0$ \\
\hline Atlantic spotted flounder & Citharus linguatula & $\mathrm{DEM} / \mathrm{ED}$ & $16 \pm 1$ & $42 \pm 15$ & $1.0 \pm 0.3$ & $0.1 \pm 0.1$ \\
\hline
\end{tabular}
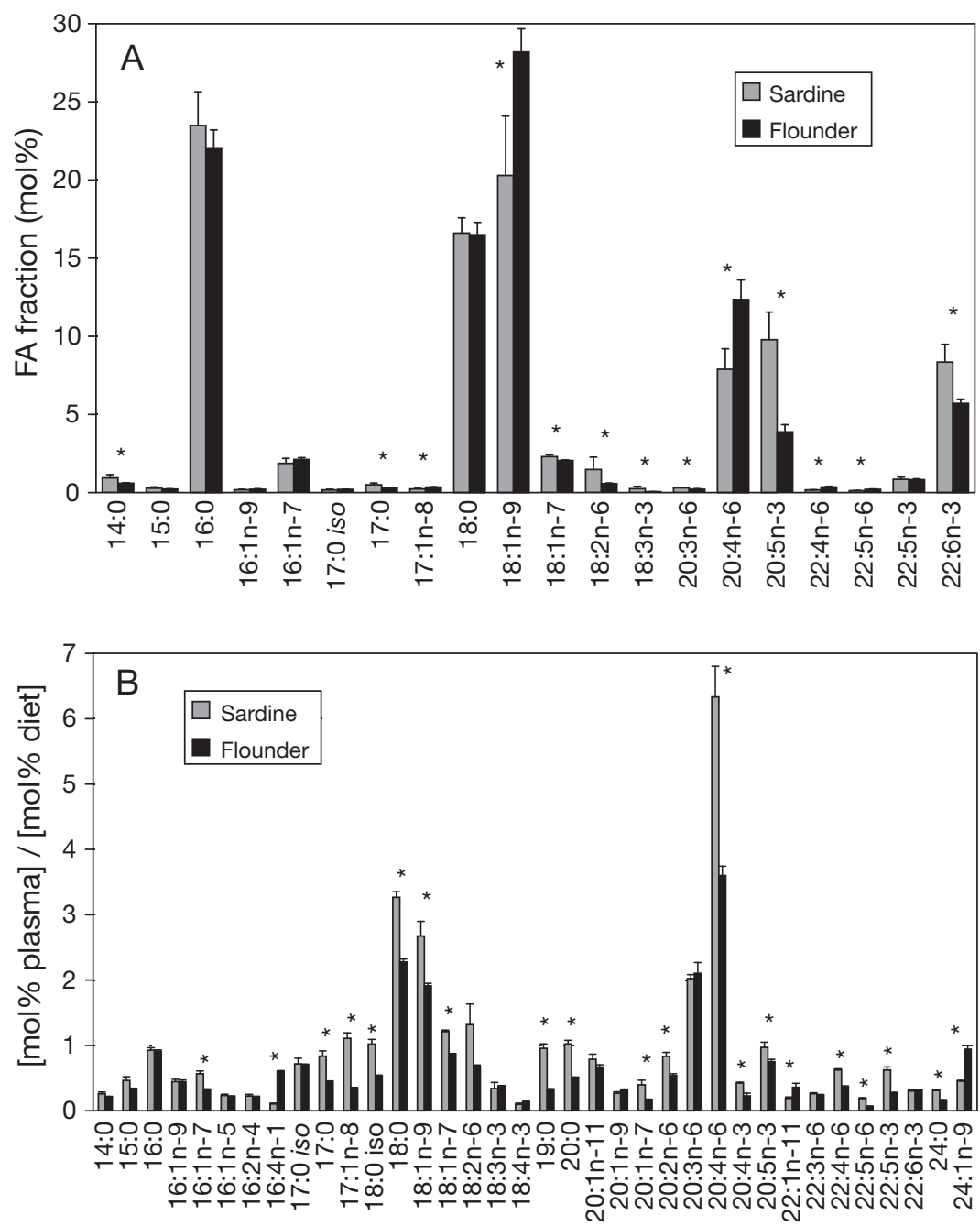

Atlantic spotted flounder, and European hake) in general had longer chains and contained more n-6 PUFAs than the PUFAs of the pelagic species. Most of the demersal species contained more C20-22 MUFAs than the pelagic species, although the spotted flounder was an exception, with a long-chain MUFA content similar to that of the planktivorous fish. Differences between fish can also be described with simple ratios. One of the clearest features distinguishing between Mediterranean pelagic and demersal fish was the ratio of n-6 PUFA to n3 PUFA, which was high (0.14-0.25) in the demersal fish and low (0.09-0.10) in pelagic species (Fig. 5A). Comparison of the metabolic counterparts 20:4n-6 and 20:5n-3 was equally effective in separating between pelagic $(0.11$ to 0.15$)$ and demersal species (0.22-0.67; Fig. 5B). In addition, the ratio of $\mathrm{C} 16-18$ PUFA to

Fig. 3. Larus michahellis. (A) Main fatty acids $(\mathrm{mol} \%$, mean $\pm \mathrm{SD}, \mathrm{n}=5$ each) in the total lipids of plasma of captive yellow-legged gulls fed the experimental sardine and Atlantic spotted flounder diets (fatty acids exceeding $0.2 \mathrm{~mol} \%$ in either group are shown). (B) Calibration factors between the proportions in the plasma and diet. Asterisks denote significant differences ( $\mathrm{p}<0.05$, Student's $t$-test) between the 2 dietary groups 
C20-22 n-6 PUFA was larger in pelagic fish (1.9-3.0) than in demersal fish (0.3-1.3; Fig. 5C). In terms of these ratios, most demersal species differed significantly from the pelagic species ( $p<0.05,1$-way ANOVA followed by Newman-Keuls test of means). It should be noted that the PUFA composition of the cephalopod (common bobtail) resembled that of the pelagic fish.

The relative standard deviations (RSD) calculated for each fatty acid in the plasma FAS of the birds indicated which fatty acids varied the most among individuals, and thus were the best candidates to reveal dietary information (Fig. 6). In the shearwater plasma, the fatty acids $18: 3 n-3,18: 4 n-3$, long chain MUFAs (especially 22:1n-11), 22:4n-6, and 22:5n-6 varied the most. The data from the captive yellowlegged gulls showed that 18:2n-6, 20:4n-3, and 20:5n-3 also have the potential to indicate diet. The potentially endogenous C16 and C18 saturated fatty acids (SFAs) and MUFAs had the lowest RSD values both in the wild shearwaters and in the captive yellow-legged gulls fed sardine or flounder.

The plasma FAS of the birds were studied by means of PCA; the shearwater samples were clearly separated from those of the captive yellow-legged gulls fed sardine or flounder (Fig. 7A). The separations were tested quantitatively by means of space filling models (SIMCA). The distances of the samples both to their own and to the other space filling models were then measured, and significant distinctions at $\mathrm{p}<0.05$ were found between all groups. The shearwater FAS were closer to those of the sardine-fed gulls but differed from them, especially by having higher levels of 20:1n-11 and 20:4n-3.

Since direct comparison of the fatty acid percentages in the bird plasma and dietary fish is inappropriate due to the metabolic modifications found in the feeding experiment, we tried to convert the shearwater plasma FAS (Supplementary Material, Table S2) back to the mean dietary FAS by using the fatty acid-specific calibration coefficients (Supplementary Material, Table S1) obtained from the feeding experi- ment of the yellow-legged gulls. The calculated FAS of the theoretical dietary lipid mixture were subjected to PCA together with the FAS of the dietary fish determined by GC (Fig. 7B). In the PCA biplot, the estimates of the shearwater diet fell closest to silvery pout, and were shifted right from sardine and anchovy. The fatty acid that in the PCA contributed most to the total variance described by the PC axis eigenvalues was
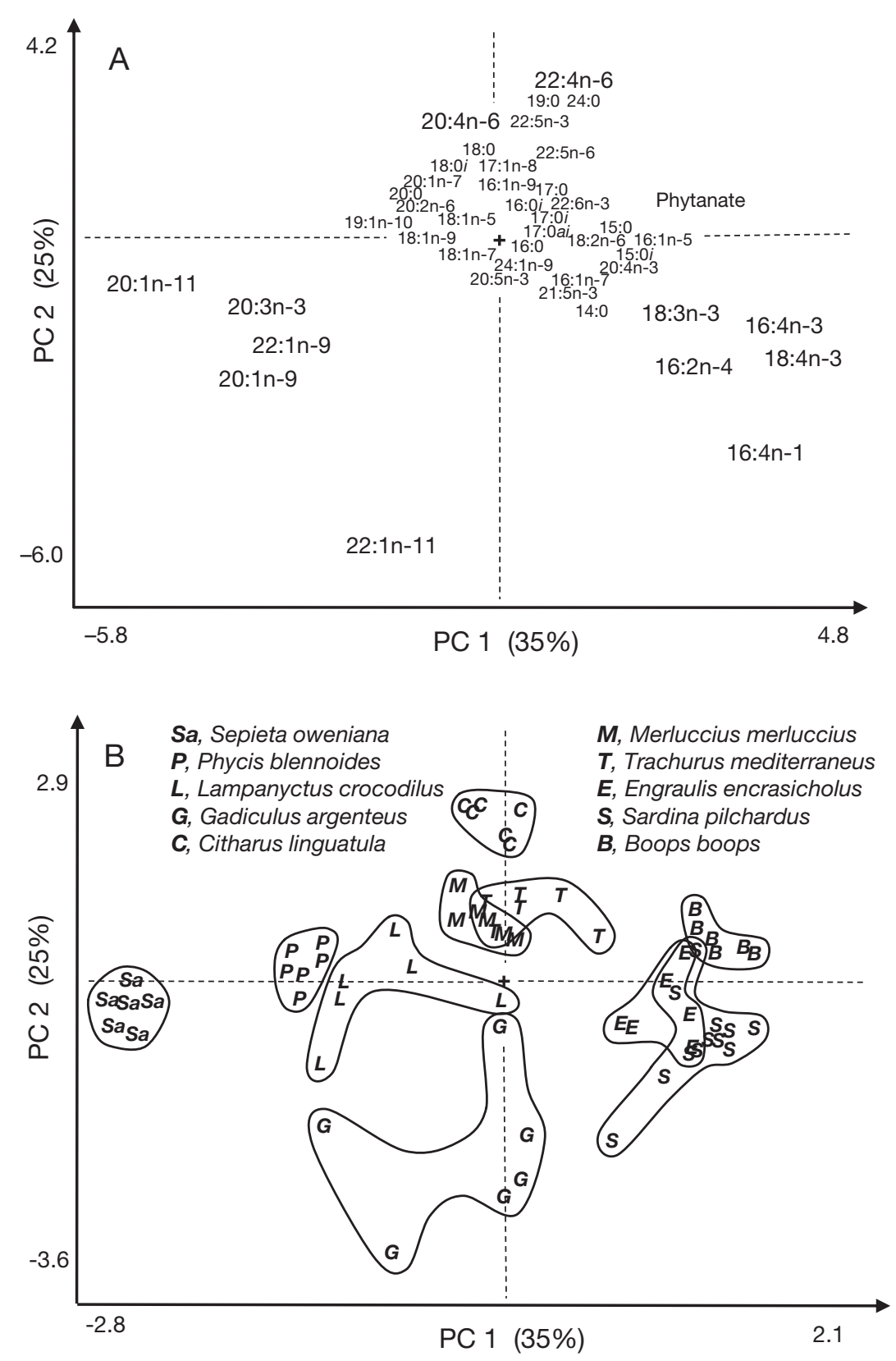

Fig. 4. (A) Loadings and (B) scores of principal component analysis of Mediterranean demersal $(P, L, G, C, M)$, pelagic predator $(T, B)$ and planktivorous $(E, S)$ fish species and a cephalopod $(S a)$. Abbreviations used for the species names are indicated in (B). Each letter code stands for 1 sample. In the fatty acid abbreviations, $i$ and ai indicate iso- and anteiso- branching of the acyl chain, respectively 

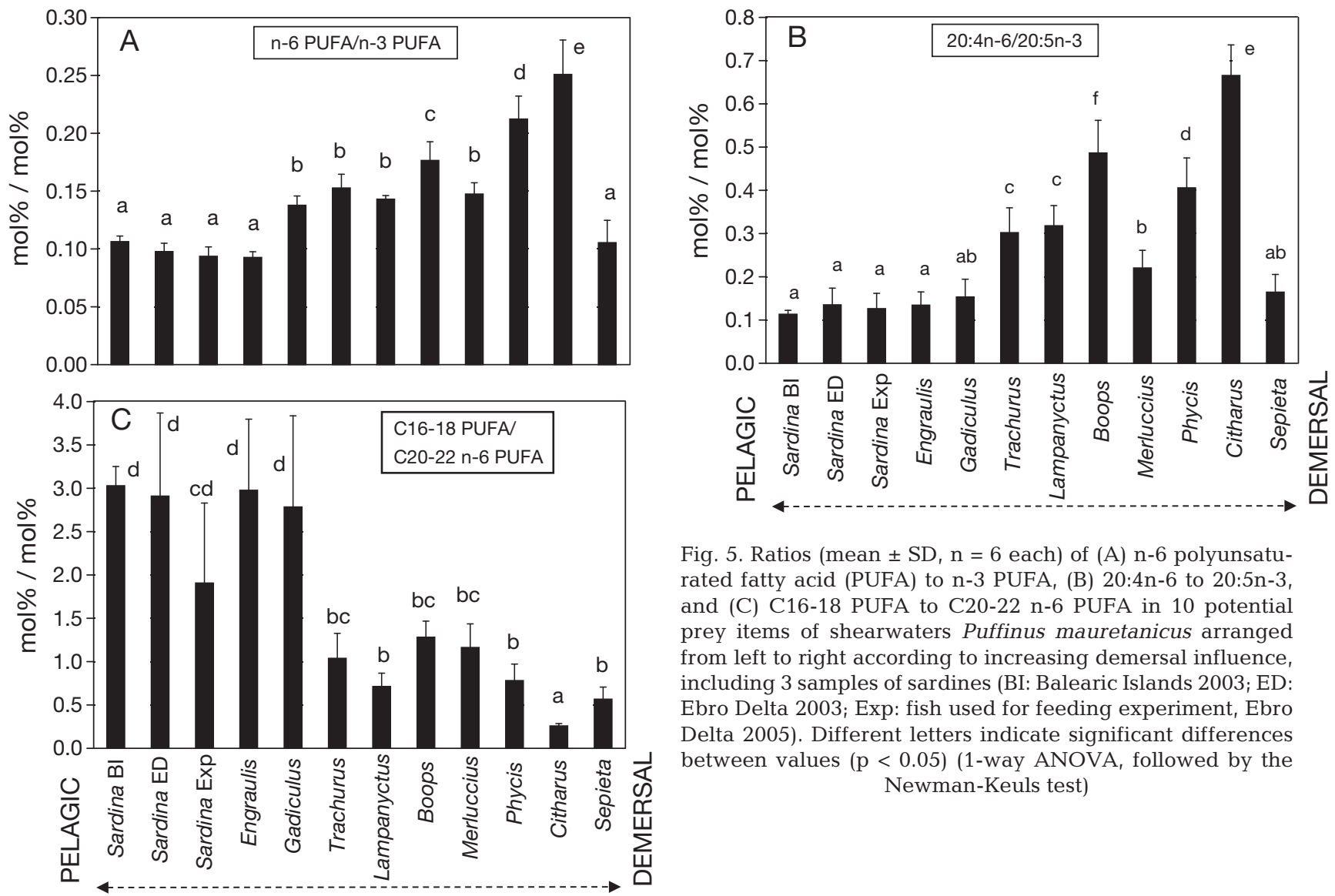

Fig. 5. Ratios (mean $\pm \mathrm{SD}, \mathrm{n}=6$ each) of $(\mathrm{A}) \mathrm{n}-6$ polyunsaturated fatty acid (PUFA) to n-3 PUFA, (B) 20:4n-6 to 20:5n-3, and (C) C16-18 PUFA to C20-22 n-6 PUFA in 10 potential prey items of shearwaters Puffinus mauretanicus arranged from left to right according to increasing demersal influence, including 3 samples of sardines (BI: Balearic Islands 2003; ED: Ebro Delta 2003; Exp: fish used for feeding experiment, Ebro Delta 2005). Different letters indicate significant differences between values $(p<0.05)$ (1-way ANOVA, followed by the

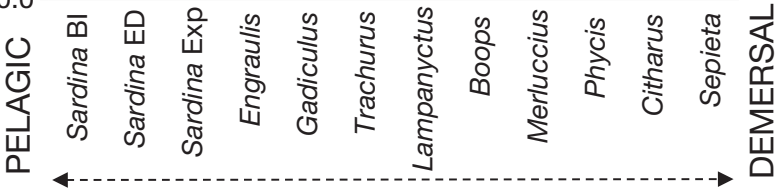
Newman-Keuls test)

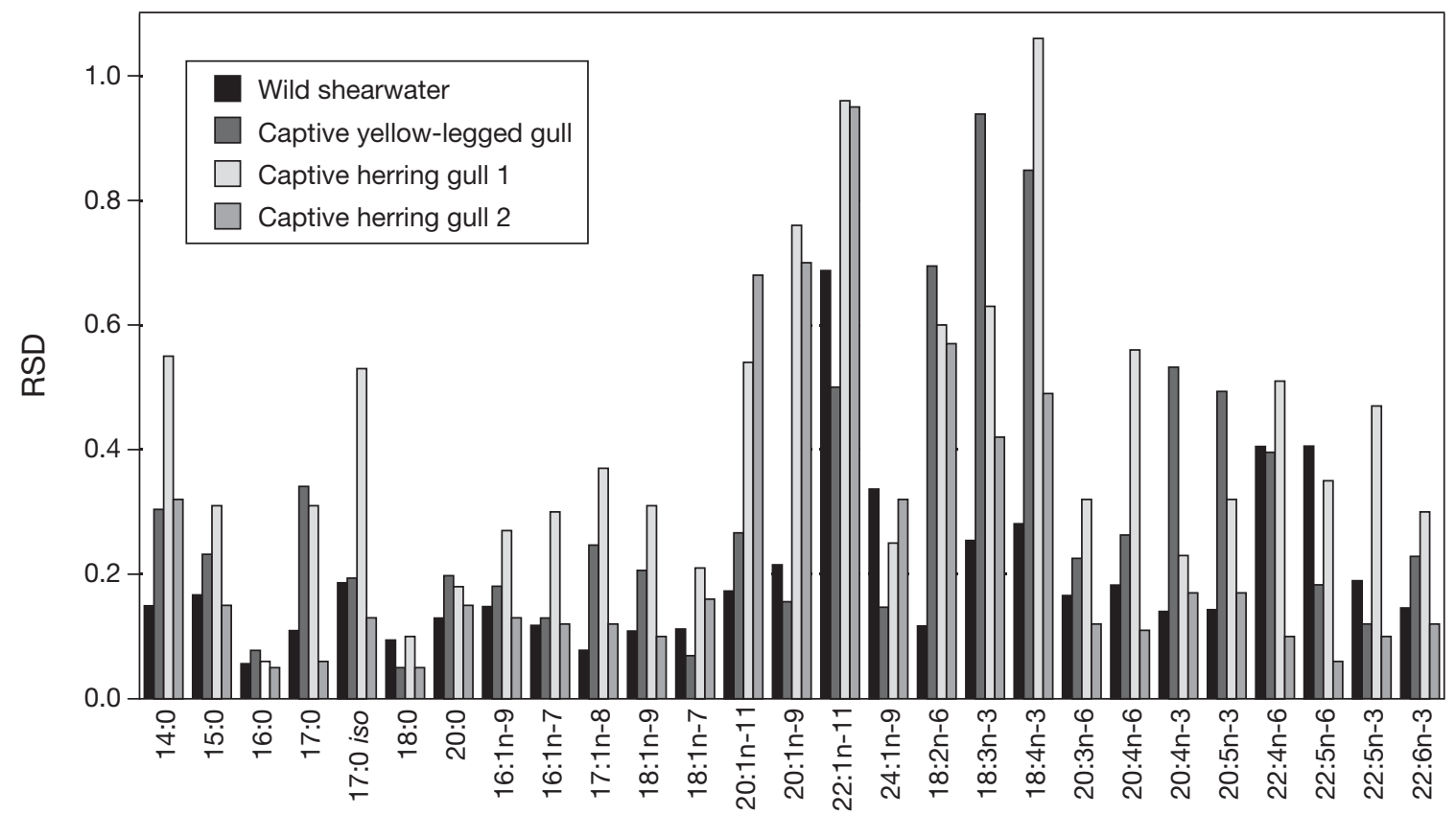

Fig. 6. Puffinus mauretanicus, Larus michahellis, and L. argentatus. Relative standard deviations (RSD) in the proportions of different fatty acids in the plasma of wild shearwaters and in plasma of captive yellow-legged gulls fed sardine or flounder. For comparison, previous data on captive herring gulls fed Atlantic herring or Atlantic spotted flounder (1; Käkelä et al. 2009) or several different Atlantic pelagic and demersal fish (2; Käkelä et al. 2005) are also included 
20:1n-11. The PUFAs 20:4n-6 and 20:5n-3 versus their metabolic precursors 18:2n-6 and 18:3n-3 (on the other side of the plot) were the next important factors explaining the total variation.
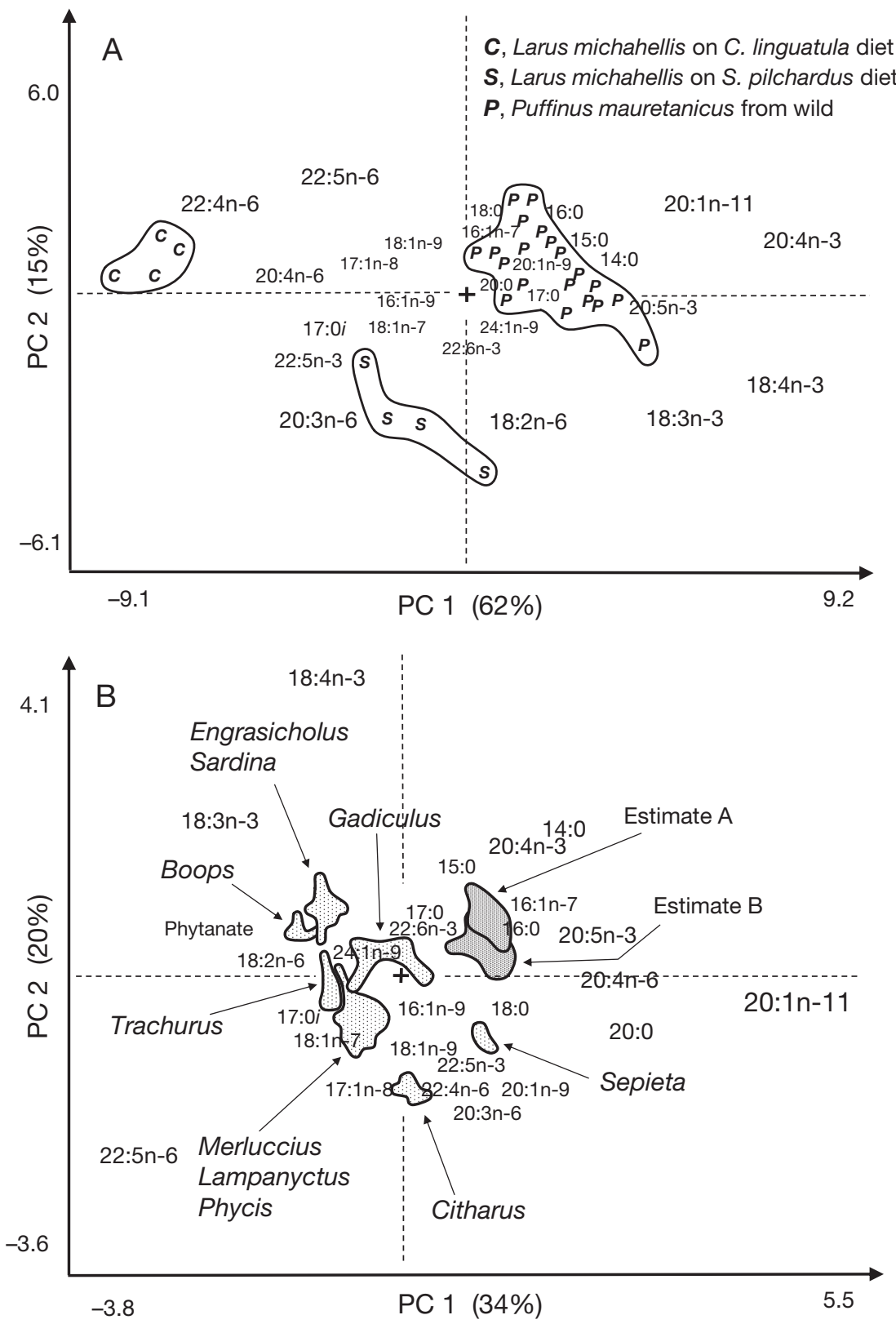

Fig. 7. Puffinus mauretanicus and Larus michahellis. Principal component biplots of (A) fatty acid signatures (FAS) of Balearic shearwater plasma samples $(P)$ compared to those from captive yellow-legged gulls fed either Atlantic spotted flounder Citharus linguatula $(C)$ or sardine Sardina pilchardus ( $S$ ) using 26 quantitatively most important fatty acids as loadings, and (B) the FAS of theoretical average dietary mixtures of lipids (calculated using the calibration factors obtained in the feeding test) compared to the FAS of potential prey. Estimate A was obtained by using the calibration factors derived from the gulls fed Atlantic spotted flounder and Estimate B derived from the gulls fed sardine. In the fatty acid abbreviations, $i$ stands for iso-branching of the acyl chain
Since the complex metabolic modifications affecting FAS of plasma samples may bias the results of the detailed indirect multivariate approach above, and the quantitative modeling of plasma FAS (e.g. by Quantitative Fatty Acid Signature Analysis, QFASA; Iverson et al. 2004) is not yet possible (given the same difficulties to address these large metabolic transformations of fatty acids), we analyzed the plasma FAS by using a more robust approach that was less vulnerable to the metabolic changes. Since the position of the last double bond of the n-6 and n-3 PUFAs (i.e. sixth or third carbon calculated from the methyl end of the chain, respectively) does not change in vertebrate lipid metabolism, the ratios of the totals of these PUFA families may in some cases indicate the diet in a more reliable way than the detailed PUFA profiles changed in a bird's metabolism. Therefore, we compared the ratio of the totals of n-6 and n-3 PUFAs in the plasma of the shearwaters and the captive yellowlegged gulls (Fig. 8A). In addition, the ratios of $20: 4 n-6$ to $20: 5 n-3$ and C16-18 PUFA to C20-22 n-6 PUFA, found to be different for the pelagic and demersal fish (Fig. 5), were also studied in the birds' plasma (Fig. 8B,C). The values of all of these PUFA ratios of the shearwater were similar to those of the sardine-fed gulls and differed at $\mathrm{p}<0.05$ from the values of the gulls fed flounder (1-way ANOVA followed by Newman-Keuls test). In addition to PUFA, the C20 and C22 MUFAs showed large inter-individual variation in the plasma of the wild shearwaters and the captive gulls, and apparently had potential to carry dietary information (Fig. 6). Therefore, the plasma levels of 20:1n-11, 20:1n-9, and 22:1n-11 were compared (Fig. 9A). The shearwater plasma contained more 20:1n-11 than the gulls either on sardine or flounder diet ( $p<0.05,1$-way ANOVA, followed by the Newman-Keuls test). Among the potential prey analyzed, the common bobtail showed the highest levels of this marker (Fig. 9B). However, birds and mammals can convert excessively consumed 22:1n11 to 20:1n-11 (see Discussion). Among the analyzed prey items, a gadid species, silvery pout, was a rich source of $22: 1 \mathrm{n}-11$. The amount of $22: 1 \mathrm{n}-11$ in the silvery pout 

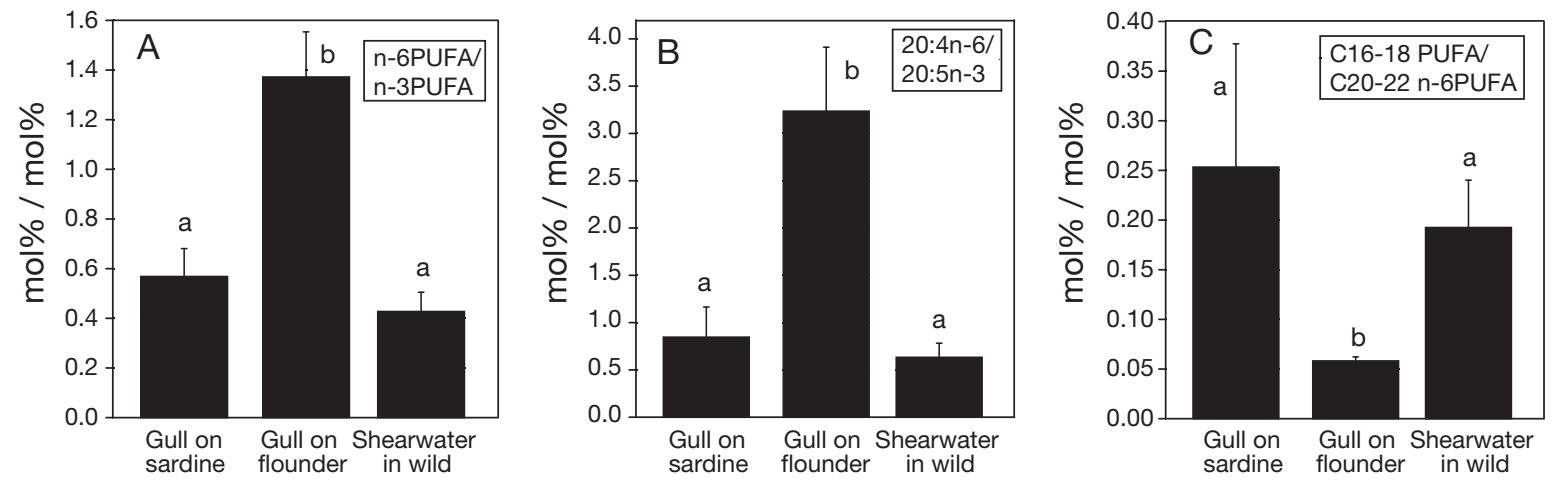

Fig. 8. Larus michahellis and Puffinus mauretanicus. Ratios of (A) n-6 PUFA to n-3 PUFA, (B) 20:4n-6 to 20:5n-3, and (C) C16-18 PUFA to C20-22 n-6 PUFA in the plasma of yellow-legged gulls (mean \pm SD, $n=5$ each) fed sardine or flounder and in plasma of wild shearwaters $(n=20)$. Different letters indicate significant differences between values $(p<0.05)(1$-way ANOVA, followed by the Newman-Keuls test)
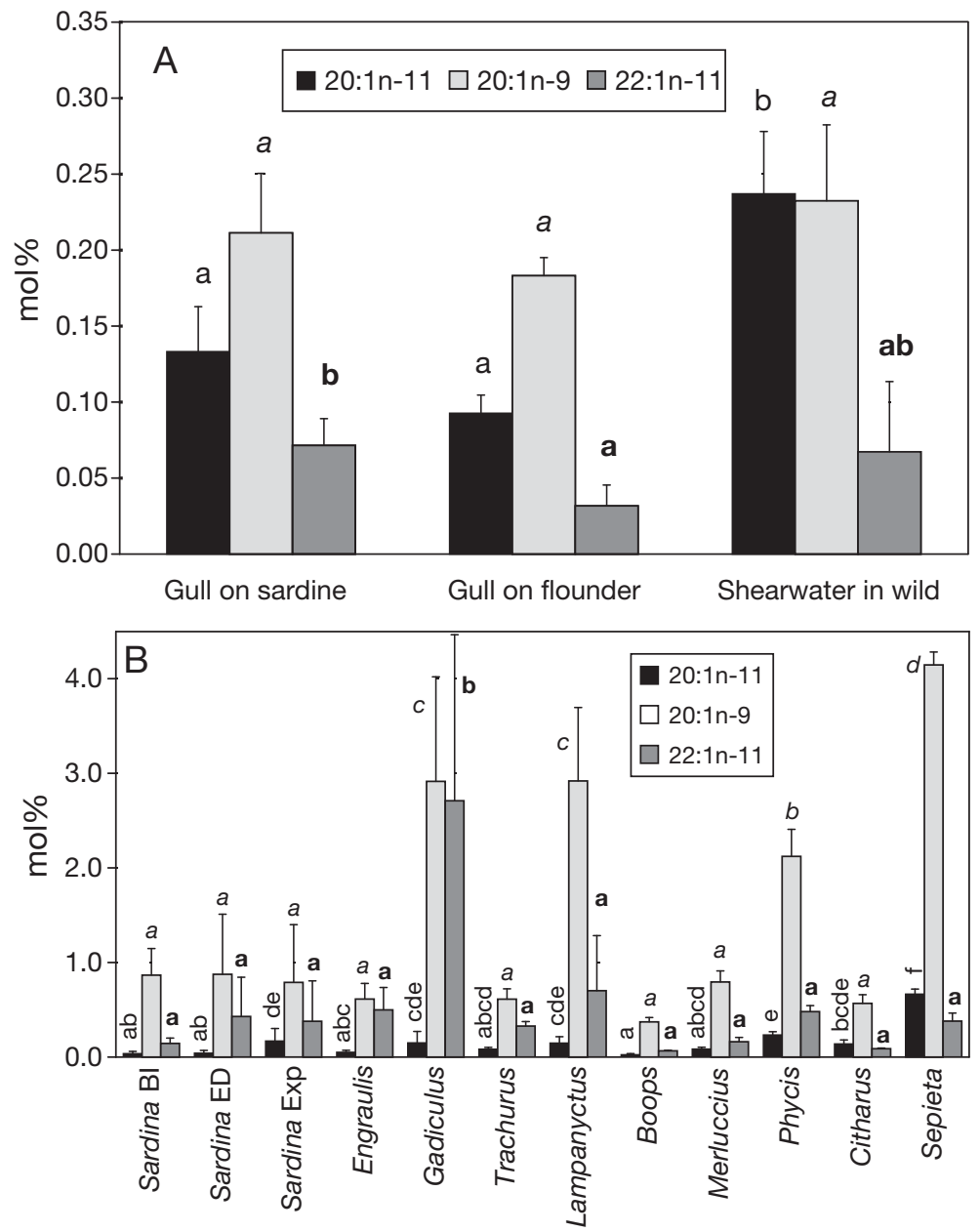

Fig. 9. Larus michahellis and Puffinus mauretanicus. Proportions of the long-chain monounsaturated fatty acids (MUFAs) 20:1n-11, 20:1n-9 and 22:1n-11 in (A) plasma of yellow-legged gulls (mol\%, mean $\pm \mathrm{SD}, \mathrm{n}=5$ each) fed sardine or flounder and in plasma of wild shearwaters $(\mathrm{n}=20)$ and (B) potential prey items $(n=6)$. Values for the same fatty acid and with no common letter differ from each other at $(p<0.05)(1$-way ANOVA followed by the Newman-Keuls test) was 5 times larger than the amount of 20:1n-11 in the bobtail $(\mathrm{p}<0.05,1$-way ANOVA followed by Newman-Keuls test).

\section{DISCUSSION}

During the 8 wk feeding experiment with captive yellow-legged gulls, the adipose tissue and plasma FAS developed fatty acid patterns characteristic of the sardine or flounder diet, showing the capability of both tissues to indicate diet. It is likely that the studied FAS had equilibrated; the plasma FAS of captive herring gulls Larus argentatus have been found to change with dietary switches in a few days (Käkelä et al. 2005, 2009), and the half-life for fatty acids of avian adipose tissue is also relatively fast, about $20 \mathrm{~d}$ in chickens (Foglia et al. 1994). The calibration factors calculated for the transfer of the signal from the diet to tissue differed considerably for individual fatty acids and in adipose tissue and plasma, and also somewhat in the 2 dietary groups (pelagic versus demersal). In addition to the well known different metabolic fates of different fatty acids in the bodies of birds and other vertebrates (Newman et al. 2002, Moussavi et al. 2008), the amount of a given fatty acid consumed or the biochemical matrix of the food may affect the absorption, transport, and metabolism of lipids and fatty acids of birds. The adipose tissue FAS of the yellow-legged gulls were in general closer to the dietary fatty acid 
composition than those of the plasma FAS, suggesting that adipose tissue biopsies are preferable for studying the feeding ecology of seabirds. However, in the case of endangered and small species, with small subcutaneous lipid reserves, there are difficulties in developing safe protocols for sampling adipose tissue. Fortunately, the results of the present calibration test, in which the adipose tissue and plasma FAS showed similar dietary responses, and a previous study (Käkelä et al. 2009), in which several fatty acids in the plasma of herring gulls responded quantitatively to dietary supply, suggest that plasma FAS are also useful for studying seabird diet.

To use FAS analysis successfully, the dietary items consumed must differ in fatty acid patterns. Our results showed that Mediterranean pelagic species contained more C16 and C18 PUFAs than the demersal species, a common feature of planktivorous fish also in the Atlantic and Pacific Oceans (Iverson et al. 2002, Käkelä et al. 2005). The demersals were instead rich in C20 and C22 n-6 PUFAs. Within Mediterranean fishes, the levels of C20 and C22 MUFAs were generally low, and the highest values were found in the demersal species (except spotted flounder), i.e. opposite to the situation in the Atlantic or Pacific (Käkelä et al. 2005, Iverson et al. 2007, Wang et al. 2007). In the oceans, levels of long-chain MUFAs are very high in pelagic fish species grazing on zooplankton, which store energy as wax esters (Saito \& Kotani 2000, Dahl et al. 2003, Käkelä et al. 2005). For example, the Atlantic sardine contains 7 mol\% 22:1n-11, whereas the Mediterranean sardine contains only 0.1 to $0.4 \mathrm{~mol} \%$. Thus, patterns of FAS established in North Atlantic and Pacific ecosystems cannot be used to infer diets of Mediterranean top predators. The Mediterranean pelagic predators, the horse mackerel and bogue, had FAS that were intermediate between the pelagic plankton feeders (on which the mackerel and bogue prey) and the demersal species that feed on various benthic and epibenthic invertebrates and remains. Altogether, the FAS of the different Mediterranean fish species differed sufficiently to allow use of different fatty acid fingerprinting methods to assess the diet of top predators (Figs. 5 \& 9B). However, for phospholipid-rich tissues, such as plasma, metabolic modifications of fatty acids are large, and a fatty acid may not reflect its own dietary level but that of its precursor. In these cases, it is useful to calculate specific key ratios between different fatty acids or between groups of metabolically related fatty acids. They simplify the analysis and indicate the relative proportions of certain types of prey (e.g. pelagic versus demersal). The ratios of n-6 to n-3 PUFAs, 20:4n-6 to $20: 5 n-3$ (which are the favored fatty acids from the n-6 and n-3 families for incorporation into lipoprotein phospholipids; Mosconi et al. 1990), and C16-18 to C20-22 n-6 PUFAs proved to be useful in this study of the Mediterranean food web.

When comparing the FAS of shearwater plasma to those of captive gulls, the shearwater PUFAs were close to those of sardine-fed gulls showing fatty acid characteristics of planktivorous fishes. However, the content of 20:1n-11 in the shearwaters' plasma was higher than that of the sardine-fed gulls. Our previous feeding experiments with herring gulls showed that even with no change in the dietary level of 20:1n-11 itself, the levels of $20: 1 \mathrm{n}-11$ rose in the plasma when the dietary amount of 22:1n-11 increased (Käkelä et al. 2009). This is due to part of the excess dietary 22:1n-11 being chain shortened in peroxisomes, which yields 20:1n-11 (Bremer \& Norum 1982, Reddy \& Hashimoto 2001). Therefore, the recent diet of the shearwaters may have contained demersal items rich in 20:1n-11 or more likely 22:1n-11.

The long-chain MUFA is also a highly valuable and sensitive marker when the adipose tissue is monitored. The present calibration test with yellow-legged gulls showed that the dietary signal of all long-chain MUFAs was amplified in the adipose tissue. High calibration factors between adipose tissue and diet have also been recorded for these fatty acids in captive common guillemots Uria aalge (Iverson et al. 2007). The signal of long-chain MUFAs is metabolically persistent, since a recent feeding test with pheasants indicated that in fasted birds, the shorter-chain fatty acids are preferentially mobilized from adipose tissue and thus the percentages of the long-chain MUFAs are elevated during food deprivation (Mustonen et al. 2009).

The attempt to transform the detailed shearwater plasma FAS (Supplementary Material, Table S2) through the calibration factors (Supplementary Material, Table S1) to the dietary fatty acid mixture of the birds proved to be difficult (Fig. 7B). With the calibration factors from the sardine- or flounder-fed gulls, the deduced estimates of the dietary FAS were shifted right on the PCA biplot from the expected positions, which would have been between the most likely pelagic prey (sardine) and a demersal gadid species (silvery pout). Thus, this approach suggested a stronger influence of demersal prey on the diet than anticipated from the simple fatty acid ratios or conventional studies of the shearwater diet (Arcos \& Oro 2002). However, the fatty acid variables responsible for this shift may have been produced from their precursors by the birds' metabolism. After the 20:1n-11, discussed earlier, the next important contributors to this shift (and the overall separation of samples in the PCA) were the PUFA precursors 18:2n-6 and 18:3n-3, which were 'too low' in the calculated estimates, and their metabolic products 20:4n-6 and 20:5n-3 (also 20:4n-3), 
which were 'too high' in the estimates. Thus, the calibration factors presumably failed to address this metabolism in the shearwater body accurately enough. The theoretically sound trial may have been hampered by interspecies metabolic differences, variations in the nutritional status, and temporal changes in the circulating lipids of wild seabirds or other factors limiting the applicability of the calibration coefficients, e.g. insufficient library of reference prey FAS. The sites of capture and sizes of the potential prey specimens analyzed overlap well with the prey consumed by Balearic shearwaters (Oro \& Ruiz 1997, Martínez-Abraín et al. 2002), but the fish fed to the gulls in the feeding experiment were of marketable size and on average larger than in a random sample. Therefore, when applying the FAS approach to plasma samples of the shearwaters, the most productive and reliable method was the direct comparison of the key ratios of PUFAs and the long-chain MUFA markers, which showed marked differences among the potential dietary fish, and the proportions of which had large deviations (RSD) in the shearwater plasma. When the present data and our previous data on captive herring gulls fed pelagic or demersal Atlantic fish (Käkelä et al. 2005, 2009) were combined, they indicated that in seabird plasma, most PUFAs and the long-chain MUFAs can vary considerably, provided that there are marked variations in the levels of these fatty acids in the diet (Fig. 6).

Our fatty acid biomarker results, especially the key ratios of PUFAs, imply that a large part of the dietary lipids of wild Balearic shearwaters came from planktivorous pelagic fish. However, the strong signal of 20:1n11, significantly higher than in the sardine-fed yellowlegged gulls, suggested that demersal items rich in long-chain MUFAs were also a part of the diet of the shearwaters. This biomarker result is consistent with previous studies on the foraging ecology of Balearic shearwaters, which estimated that about $40 \%$ of the energy supply for the species comes from trawler discards comprising both pelagic and demersal fishes (Arcos \& Oro 2002). However, Balearic shearwater distribution at mid- and large scales does not seem to be determined by trawlers, suggesting that discards represent an opportunistic foraging resource when this fishery operates within their foraging grounds (Louzao et al. 2006b). Thus, foraging on shoaling pelagic fish is likely an important feeding resource during the breeding season (Arcos \& Oro 2002), although the fatty sardine also makes up a major proportion of the catches and discards of the fisheries (Martínez-Abraín et al. 2002).

Fatty fish provide more fatty acids and influence tissue FAS to a greater extent than the same mass of lean fish. Among the studied potential dietary items of the Mediterranean, sardine had high lipid content $(8 \%$ in the specimens from the Balearic archipelago) but all other species, including all demersal species, were relatively lean. In theory, the lean species should be consumed considerably more compared to sardine to get an equal fatty acid signal into the birds' tissues. We incorporated the present lipid content data of the different Mediterranean fish species into data of fish selection by shearwaters at discarding fishing vessels (Arcos \& Oro 2002). Based on the recorded proportion of different fish species in discards, the preferences of catching them by shearwaters, and the lipid content of prey species, we estimated the amount of fatty acids coming from different discarded fish. In these discarding experiments, ca. $52 \%$ of the fatty acids consumed by shearwaters were derived from sardine, ca. $18 \%$ from different Gadiformes species (silvery pout is rich in $22: 1 \mathrm{n}-11), 12 \%$ from anchovy, and ca. $17 \%$ from other species. The strong signal of pelagic types of PUFA in the shearwater plasma FAS found in the present study is in accordance with the sardine and other pelagic planktivorous species being the preferred dietary items. Consistent with the field study suggesting that various Gadiformes are the next most important prey, the determined plasma FAS of the shearwaters deviated from those of the sardine-fed gulls by having high proportions of 20:1n-11 (suggesting dietary supply of 22:1n-11). Our survey of FAS in different prey also suggests that this signal had likely come from demersal species.

This first application of FAS to study the feeding ecology of Mediterranean seabirds proves the usefulness of this tool to further improve our understanding of the food webs of this marine ecosystem. The accuracy of the diet estimations provided by the FAS can be improved by developing cautious and safe protocols for adipose tissue biopsy and collecting a larger reference library of prey FAS including different age and size classes of fish. The captive feeding experiment showed that similar interpretations could be inferred from adipose tissue and plasma FAS. Thus, large-scale monitoring programs (where birds are sampled repeatedly in several locations) can benefit from both plasma and adipose tissue FAS. These markers may vary spatially or temporally in response to environmental changes (including climate change or fishing practices), and thus might detect early ecosystem changes, some related to management actions such as fishing regulations.

Acknowledgements. This paper is a contribution to the EU DISCBIRD project 'Effects of changes in fishery discarding rates on seabird communities' (contract Q5RS-2001-00839). We thank J. M. Igual, I. Afán, and M. G. Forero for help during the fieldwork at the breeding colonies; B. Morales and her team for their facilities; and J. M. Arcos for discussions. At sea, this work would have been impossible without the help of several skip- 
pers from the Balearic Islands and all participants in the MEDITS series cruises on board RV 'Cornide de Saavedra', especially L. Gil de Sola and P. Abelló. Permits were provided by Generalitat Valenciana (Conselleria de Territorio y Vivienda) and Govern de les Illes Balears (Conselleria de Medi Ambient). M.L. was supported by a fellowship of Conselleria de Innovació, Hisenda i Economia (Govern de les Illes Balears).

\section{LITERATURE CITED}

Ackman RG (1992) Application of gas-liquid chromatography to lipid separation and analysis: qualitative and quantitative analysis. In: Chow CK (ed) Fatty acids in foods and their health implications. Marcel Dekker, New York, p 47-63

Alverson DL (1998) Discarding practices and unobserved fishing mortality in marine fisheries: an update. Washington Sea Grant Program. University of Washington, Seattle, WA

Arcos JM, Oro D (2002) Significance of fisheries discards for a threatened Mediterranean seabird, the Balearic shearwater Puffinus mauretanicus. Mar Ecol Prog Ser 239:209-220

Arcos JM, Louzao M, Oro D (2008) Fisheries ecosystem impacts and management in the Mediterranean: seabirds' point of view. Am Fish Soc Symp 49:587-596

Arnau P, Liquete C, Canals M (2004) River mouth plume events and their dispersal in the Northwestern Mediterranean Sea. Oceanography (Wash DC) 17:23-31

> Barrett RT, Camphuysen KCJ, Anker-Nilssen T, Chardine JW and others (2007) Diet studies of seabirds: a review and recommendations. ICES J Mar Sci 64:1675-1691

Bertrand JA, Gil de Sola L, Papaconstantinou C, Relini G, Souplet A (2002) The general specifications of the MEDITS surveys. Sci Mar 66:9-17

Bremer J, Norum KR (1982) Metabolism of very long-chain monounsaturated fatty acids $(22: 1)$ and the adaptation to their presence in the diet. J Lipid Res 23:243-256

$>$ Dahl TM, Falk-Petersen S, Gabrielsen GW, Sargent JR, Hop $\mathrm{H}$, Millar RM (2003) Lipids and stable isotopes in common eider, black-legged kittiwake and northern fulmar: a trophic study from an Arctic fjord. Mar Ecol Prog Ser 256:257-269

Foglia TA, Cartwright AL, Gyurik RJ, Philips JG (1994) Fatty acid turnover rates in the adipose tissues of the growing chicken (Gallus domesticus). Lipids 29:497-502

Folch J, Lees M, Sloane-Stanley GH (1957) A simple method for the isolation and purification of total lipides from animal tissue. J Biol Chem 226:497-509

Furness RW, Edwards AE, Oro D (2007) Influence of management practices and of scavenging seabirds on availability of fisheries discards to benthic scavengers. Mar Ecol Prog Ser 350:235-244

Garthe S, Hüppop O (1994) Distribution of ship-following seabirds and their utilization of discards in the North Sea in summer. Mar Ecol Prog Ser 106:1-9

Garthe S, Camphuysen KCJ, Furness RW (1996) Amounts of discards by commercial fisheries and their significance as food for seabirds in the North Sea. Mar Ecol Prog Ser 136:1-11

Iverson SJ, Frost KJ, Lang SLC (2002) Fat content and fatty acid composition of forage fish and invertebrates in Prince William Sound, Alaska: factors contributing to among and within species variability. Mar Ecol Prog Ser 241:161-181

Iverson SJ, Field C, Bowen WD, Blanchard W (2004) Quantitative fatty acid signature analysis: a new method of estimating predator diets. Ecol Monogr 74:211-235
Iverson SJ, Springer AM, Kitaysky AS (2007) Seabirds as indicators of food web structure and ecosystem variability: qualitative and quantitative diet analyses using fatty acids. Mar Ecol Prog Ser 352:235-244

Käkelä R, Käkelä A, Kahle S, Becker PH, Kelly A, Furness RW (2005) Fatty acid signatures in plasma of captive herring gulls as indicators of demersal or pelagic fish diet. Mar Ecol Prog Ser 293:191-200

Käkelä A, Crane J, Votier SC, Kahle S, Furness RW, Käkelä R (2006) Fatty acid signatures as indicators of diet in great skuas Stercorarius skua, Shetland. Mar Ecol Prog Ser 319:297-310

Käkelä A, Furness RW, Kelly A, Strandberg U, Waldron S, Käkelä R (2007) Fatty acid signatures and stable isotopes as dietary indicators in North Sea seabirds. Mar Ecol Prog Ser 342:291-301

Käkelä R, Furness RW, Kahle S, Becker PH, Käkelä A (2009) Fatty acid signatures in seabird plasma are a complex function of diet composition - a captive feeding trial with herring gulls. Funct Ecol 23:141-149

Kvalheim OM, Karstang TV (1987) A general-purpose program for multivariate data analysis. Chemom Intell Lab Syst 2:235-237

Louzao M, Igual JM, McMinn M, Aguilar JS, Triay R, Oro D (2006a) Small pelagic fish, trawling discards and breeding performance of the critically endangered Balearic shearwater: improving conservation diagnosis. Mar Ecol Prog Ser 318:247-254

> Louzao M, Hyrenbach KD, Arcos JM, Abelló P, Gil de Sola L, Oro D (2006b) Oceanographic habitat of a critically endangered Mediterranean procellariiform: implications for the design of Marine Protected Areas. Ecol Appl 16: 1683-1695

Martínez-Abraín A, Maestre R, Oro D (2002) Demersal trawling waste as a food source for Western Mediterranean seabirds during the summer. ICES J Mar Sci 59:529-537

- Mosconi C, Coll S, Tremoli E, Galli C (1990) Dietary n-9, n-6, and n-3 fatty acids modify linoleic acid more than arachidonic acid levels in plasma and platelet lipids and minimally affect platelet thromboxane formation in the rabbit. J Nutr Biochem 1:565-571

Moussavi N, Gavino V, Receveur O (2008) Could the quality of dietary fat, and not just its quantity, be related to risk of obesity? Obesity (Silver Spring) 16:7-15

Mustonen AM, Käkelä R, Asikainen J, Nieminen P (2009) Selective fatty acid mobilization from adipose tissues of the pheasant (Phasianus colchicus mongolicus) during food deprivation. Physiol Biochem Zool 82:531-540

Newman RE, Bryden WL, Fleck E, Ashes JR, Buttemer WA, Storlien LH, Downing JA (2002) Dietary n-3 and n-6 fatty acids alter avian metabolism: metabolism and abdominal fat deposition. Br J Nutr 88:11-18

Oro D (1999) Trawler discards: a threat or a resource for opportunistic seabirds? In: Adams NJ, Slotow RH (eds) Proc 22nd Int Ornithol Congr, Durban. BirdLife South Africa, Johannesburg, p 717-730

> Oro D, Ruiz X (1997) Seabirds and trawler fisheries in the northwestern Mediterranean: differences between the Ebro Delta and the Balearic Islands areas. ICES J Mar Sci 54:695-707

Oro D, Bosch M, Ruiz X (1995) Effects of a trawling moratorium on the breeding success of the yellow-legged gull Larus cachinnans. Ibis 137:547-549

> Oro D, Genovart X, Ruiz X, Jimenez J, Garcia-Gans J (1996) Differences in diet, population increase and breeding performance between two colonies of Audouin's gulls Larus audouinii during breeding seasons affected by a trawling 
moratorium. J Avian Biol 27:245-251

Oro D, Aguilar JS, Igual JM, Louzao M (2004) Modelling demography and extinction risk in the endangered Balearic shearwater. Biol Conserv 116:93-102

Reddy JK, Hashimoto T (2001) Peroxisomal $\beta$-oxidation and peroxisome proliferator-activated receptor $\alpha$ : an adaptive metabolic system. Annu Rev Nutr 21:193-230

Ruíz A, Martí R (eds) (2004) La Pardela Balear. SEO/BirdlifeConselleria de Medi Ambient del Govern de les Illes Balears, Madrid

Saito H, Kotani Y (2000) Lipids of four boreal species of calanoid copepods: origin of monoene fats of marine animals at higher trophic levels in the grazing food chain in the subarctic ocean ecosystem. Mar Chem 71:69-82

Salat J (1996) Review of hydrographic environmental factors that may influence anchovy habitats in the northwestern Mediterranean. Sci Mar 60(S2):21-32

Sergio F, Newton I, Marchesi L (2005) Top predators and biodiversity. Nature 436:192

Svane I (2005) Occurrence of dolphins and seabirds and their consumption of by-catch during prawn trawling in Spencer Gulf, South Australia. Fish Res 76:317-327

Thiemann GW, Iverson SJ, Stirling I (2007) Variability in the blubber fatty acid composition of ringed seals (Phoca hispida) across the Canadian Arctic. Mar Mamm Sci 23: 241-261

Thompson KR, Riddy MD (1995) Utilization of offal and discards from 'fin-fish' trawlers around the Falkland Islands

Editorial responsibility: Hans Heinrich Janssen, Oldendorf/Luhe, Germany by the black-browed albatross Diomedea melanophris. Ibis 137:198-206

Votier SC, Furness RW, Bearhop S, Crane JE, and others (2004) Changes in fisheries discard rates and seabird communities. Nature 427:727-730

Votier SC, Bearhop S, Fyfe R, Furness RW (2008) Temporal and spatial variation in the diet of a marine top predator - links with commercial fisheries. Mar Ecol Prog Ser 367:223-232

> Wang SW, Iverson SJ, Springer AM, Hatch SA (2007) Fatty acid signatures of stomach oil and adipose tissue of northern fulmars (Fulmarus glacialis) in Alaska: implications for diet analysis of procellariiform birds. J Comp Physiol [B] 177:893-903

- Wang SW, Iverson SJ, Springer AM, Hatch SA (2009) Spatial and temporal diet segregation in northern fulmars Fulmarus glacialis breeding in Alaska: insights from fatty acid signatures. Mar Ecol Prog Ser 377:299-307

Wells BK, Field JC, Thayer JA, Grimes CB and others (2008) Untangling the relationships among climate, prey and top predators in an ocean ecosystem. Mar Ecol Prog Ser 364: $15-29$

Wold S, Sjöström M (1977) SIMCA; a method for analyzing chemical data in terms of similarity and analogy. In: Kowalski BR (ed) Chemometrics: theory and applications. Symp Ser Am Soc 52:243-282

Zotier R, Bretagnolle V, Thibault JC (1999) Biogeography of the marine birds of a confined sea, the Mediterranean. J Biogeogr 26:297-313

Submitted: October 8, 2008; Accepted: September 1, 2009 Proofs received from author(s): December 4, 2009 